\title{
The Costs of Activity-Based Management
}

\author{
by
}

\section{Peter Armstrong}

Acknowledgement. The Author would like to acknowledge the valuable comments of

Dave Dugdale, Colwyn Jones, Rolland Munro and Anthony Hopwood. The errors and omissions which remain are entirely the author's own.

Deleted: Department of Management $\pi$

University of Keeleף

Address for correspondence: Department of Management

Keele University 9

Staffordshire ST5 5BG

Tel 017825836019

Fax 017825842729

e-mail

p.j.armstrong@mngt.keele.ac.ukף 


\section{Abstract}

Activity-based costing and management are now the stock-in-trade of a lucrative industry, with at least one Big Six consultancy operation devoted wholly to their promotion. Both techniques represent a major extension of accountability in the modern corporation, into a zone previously defined in accounting terms as fixed overhead. The mechanics depend on treating the staff department as a mass-producer of repeated acts of routine service ('activities') performed ‘for’ particular cost-objects, usually products. By treating these activities as performance indicators, payroll budgets can be linked to activity volumes thus creating pressures for the casualisation of staff employment. The activity frame of reference, particularly when linked with 'value analysis', also encourages the stripping-out of all staff work which cannot be accommodated within its definition of activities. This threatens a dumbing-down of staff departments in which nonroutine initiatives aimed at competitive advantage in fields such as human resource management or marketing may be stifled because they cannot be accommodated within the language of accountability imposed by ABM.

These arguments are concretised through an examination of the ABM treatment of one of its favoured targets: the purchasing function. The contrast between this and the supply chain management approach advocated by practitioners and academics who take the function seriously is a stark illustration of the limitations of ABM as an approach to the management of staff activity. 


\section{Introduction: $A B C$ and the Politics of Fixed Overhead}

\section{Fixed Overhead as an Employment Shelter}

Writing in the 1970s, against a background of rising unemployment, increased casualisation and escalating industrial unrest, Freedman (1976) found it useful to visualise the working population as engaged in a 'search for shelters'. The shelters she had in mind were of two kinds: the systems of employment protection created by trade unions and professional associations and internal labour markets within the capitalist corporation itself, which existed as a result of the incomplete development of its systems of accountability and control. Where manufacturing operations were increasingly subject to the disciplines of budgetary control and standard costing ${ }^{1}$, staff departments, such as marketing, personnel management and accounting itself, remained accountable only through the discursive medium of the management committee. The result was a marked contrast between conditions inside and outside the regime of management accountancy. On the one hand, the wages of the production worker, and to some extent, those of the supervisor and junior manager were treated as a variable costs of production, to be adjusted in line with output, so far as was permitted by trade unionism and government regulation (Armstrong, 1994; Armstrong, Marginson, Edwards \& Purcell, 1996, in press). Employment in the staff department, on the other hand, remained relatively secure, depending on the abilities of its representatives to convince the rest of the management team of the importance of the services which it provided. Specimens of the rhetorics of justification developed by the managerial 'professions' are given in Armstrong (1984, 1985), and some from the purchasing function are given later in this paper (page 28).

For those who felt that they were the ones who bore the cost (and absorption costing systems could have been designed to confirm the suspicions of line managers in this regard), the comparative lack of accountability within staff departments fuelled the suspicions unsurpassably expressed in Parkinson's laws of bureaucratic expansion: 
'Work expands to fill the time available for its completion.' and '[Staff numbers increase] irrespective of variations in the amount of work (if any) to be done.' (1965, p. 11, 20). For those who could hack it into a staff position through the thickets of credentialism and the staff appraisal process the prize was a predictable career progression, topped off with a pension at the end. The resulting stable core of 'knowledge workers' was accepted as indispensable to corporate prosperity by management consultants and labour process commentators alike (Atkinson, 1984; Gordon, Edwards and Reich, 1982). In a sense, too, the indispensability of these core employees was written into the accounting system, in that their wage and salary costs were treated as fixed overhead, to be absorbed by products and processes. Like the stomach in Coriolanus, the security of the staff was supposed to work for the benefit of all. In justice therefore, all should bear the cost. Fixed overhead both coincided with, and defined, a zone of unaccountability, hedged about by real complexity and quasi-professional mystique. In Freedman's (1976) sense, fixed overhead was a shelter.

There were, however, mutterings. From the economic point of view, the escalation of fixed overhead had been the subject of concern from the days when the accepted terminology was that of 'office costs' (Curtown, 1960). From the functional point of view, there were those like the shopfloor worker interviewed by the author in the late 1970s who wondered, 'what the hell are they doing all day up there in those offices?' The gut instinct that the privileges enjoyed by staff departments were an unjustifiable burden on those who performed the 'real' work of manufacturing found expression in management academia as well as the works canteen (Child et al, 1983). As the recession of the early 1980s added bite to the question of whether fixed costs really were fixed, there were reports that senior managements were responding out of the same instincts, with personnel departments a particular candidate for run-down or contracting out 
(Torrington and Mackay, 1986). Though fixed overhead remained a shelter there was illwill enough on the outside to create a market for some means of undermining it.

\section{ABC, the Productivist Instinct, and the Project of Staff Accountability}

On the surface, activity-based costing (ABC) appeared to have nothing to do with all this, except, perhaps, for the production-centred mindset which propelled its development. As is well-known, the original concern was with manufacturing competitiveness. Traditional systems of absorption costing, it was observed, treated indirect costs as a homogenous lump, to be allocated to product lines on a single volume-related base, often direct labour. As a consequence, costs which were 'really' driven by variety, activity changes or some other form of complexity, were over-allocated to high-volume, labour intensive products and under-allocated to short-run capital intensive specialist items ${ }^{2}$. The result was said to be a systematic distortion of manufacturing strategy which favoured the pursuit of specialist niche markets rather than head-to-head competition in the world's mass markets (e.g. Kaplan, 1987, p. 7.16 Johnson and Kaplan, 1987, p. 190).

It was at this point, that the advocacy of $\mathrm{ABC}$ connected with long-standing concerns about the growth of fixed overhead as a proportion of total costs. In discovering the activities through which overhead could be allocated, ABC could also claim to have located the levers through which it could be controlled. Johnson and Kaplan's promise of a means of tackling the 'problem [of the] growth in support personnel' (1987, p. 244) might be read as an answer to the Earl of Curtown's plaint about 'rising office costs' made at a Summer School of the Institute of Chartered Accountants, England and Wales (ICAEW) almost thirty years earlier (Curtown, 1960).

The distortions of managerial decision-making through the 'misallocation' of indirect costs may have been endorsed and exacerbated by two strands of 1970s managerial doctrine. The first was a heavy emphasis on strategic management, with its insistence on questioning 'the business we are in' (e.g. Argenti, 1968). This encouraged a continual, 
not to say neurotic, scrutiny of the profitability of all product lines (as distorted by traditional absorption costings), in which their discontinuation was permanently on the agenda. The second was the then fashionable doctrine of 'flexible specialisation', according to which the corporate winners in the 'Second Industrial Divide' would be those who succeeded in the creation and pursuit of increasingly sophisticated and dynamic consumer demands (Piore \& Sabel, 1984). This school of thought may have further prejudiced senior managements against continuing to compete in the world's mass markets.

ABC was not an isolated development, but one strand of a complex productivist reaction to the managerial thinking outlined above. As an intellectual movement, this reaction was prominent in the Harvard Business School of the early 1980s. In reaction to the increasing penetration of Far Eastern manufactures into US mass markets, there was a new emphasis on manufacturing competence as a competitive force (e.g. Skinner, 1985, Cooper and Kaplan, 1991, p. 396) together with a corresponding rejection of the tendency of strategic management to seek refuge in softer markets (Hayes and Abernathy, 1980 ). These messages connected with a receptive audience: the Hayes-Abernathy paper was one of the most-requested reprints ever published by the Harvard Business Review.

Against this background, there was a ready market for a manufacturing-friendly revolution in cost accounting, and it is significant that an early exposition of Kaplan's ideas (1985) was first published in a reader co-edited by Hayes. Outside Harvard Business School, ABC's message ${ }^{3}$ that America's mass products were actually more profitable than had previously been thought chimed well with the new 'stand and fight through manufacturing' mentality. Intellectually fortified by a version of costing history which glorified the prime cost monitoring systems developed by line managers, whilst simultaneously excoriating the corruptions introduced by financial accountants in the name of inventory valuation (Johnson and Kaplan, 1987, Chs. 2, 3 and 6), the message of 
the new costing fell on receptive ears. In the UK, the roadshow 'An Evening with Robert Kaplan’ was a (very expensive) sell-out amongst line managers who did not like accountants very much. Of these there were quite a few.

In its detailed technology too, $\mathrm{ABC}$ was attractive to the line or production manager. Firstly, it made overhead costs behave as production managers thought they ought to (e.g. Bhimani and Pigott, 1992; Ruhl and Bailey, 1994; Cooper, 1990a). As has been pointed out by Armstrong ( 1995) acceptability to managerial common-sense has always been an important determinant of the direction of cost accounting evolution. More important were the implicit messages of $\mathrm{ABC}$ about the relationships which ought to obtain between staff and line departments. By distributing the costs of staff departments through the activities which they performed 'for' products and processes, $\mathrm{ABC}$ articulated the belief that these are the only valid staff activities. In its prescription of multi-functional committees as a means of implementation (e.g. Cooper et al, 1992, Innes and Mitchell, 1990), moreover, $\mathrm{ABC}$ promised the production function a major say in determining the services of which it bore the cost. As part of the same deal, the scrutiny of staff departments through which its activities were to be established could be used to reveal any which were 'non valueadded' (e.g. Hixon, 1995), thus creating a respectable front for the productivist suspicion that quite a lot of staff activity is of no value at all. It is no accident that some of the most successful applications of ABC have been initiated by operational managers (Kaplan, 1987b, p. 297; Lyne and Freidman, 1996) and also no accident that some applications have resulted in job losses in the staff departments (Pattison and Gavan, 1994; Groot, 1997). In summary, ABC found a receptive audience amongst line or production managers because it proposed that staff departments should be subjected to regimes of accountability similar to those already experienced by manufacturing. Better still, this accountability, if not actually to manufacturing managers, was in terms which they could accept as valid. 
Although ABC has subsequently been applied in a variety of settings, such as financial services (Adams, 1996), education (Acton and Cotton, 1997) and health care (Aird, 1996), and to a variety of cost-objects other than products, such as market segments (Adams, 1996), the suppliers of goods and services (Lere and Saraph, 1995) and the 'services' provided to divisions and business units by a corporate-level finance function (Cooper et al, 1992), the view which it takes of staff activity has remained true to its productivist origins. Whatever the setting, the staff department is defined as a 'service function' (e.g. Innes and Mitchell, 1990, p. 5), its workers are 'support personnel' (Johnson and Kaplan, 1987, p. 244) and the services performed are taken to be 'for' the cost-object.

If $\mathrm{ABC}$ began the process of dismantling the 'shelter' of fixed overhead, by specifying and costing the services for which it was paying, its mutation into activity-based management (ABM) promises to complete it. The key manoeuvre in this transformation is expressed in Innes and Mitchell's (1990) account of the benefits of ABC:

Process control information was enhanced by using a measure of the volume of each activity (the cost driver) to generate a cost rate which could be used not only to cost production but also as a performance measure for the activity concerned.

Once the activities through which $\mathrm{ABC}$ distributes indirect costs are regarded as nonfinancial indicators of performance for the staff department, its destruction as an enclave of unaccountability becomes straightforward. Budgetary forecasts and reports can be made in terms of the projected and actual levels of each activity, so that the department is opened up to a variant of standard costing. The implications for the future of the staff department as an employment shelter have been forcefully spelt out from the security of a tenured professorship at Harvard Business School. This is ‘Kaplan’s first law of fixed and variable costs': 
'If there is more than one person in a department, it is a variable cost. If there is more than one machine in a department, machines are a variable cost. If there is more than one of any resource, it has got to be a variable cost resource.'

(Kaplan, 1987, p. 7.18)

\section{The Future of the Staff Functions under ABM}

The destruction of the staff department as a shelter is not incidental to ABM: it is the heart of it. In this respect, its promotion by accounting academics and consultants is a prime example of the politics of the capitalist agency relationship (Armstrong, 1991). On this view of the modern corporation, managerial hierarchies consist, not only of a progressive subdivision of tasks and responsibilities, but also of a chain of agency relationships, in which subordinates are necessarily trusted to act in the interests of their superiors (i.e., as their agents). Senior managers, however, have a choice as to who they will trust. Since there are managerial occupations which profess techniques through which others can be monitored and controlled, senior managers can choose to trust these as an alternative to trusting the managers of the functions concerned. From this point of view, $\mathrm{ABM}$, in its most ambitious expositions, constitutes a claim that management accountancy can now construct regimes of accountability applicable to all staff functions. Besides the implications for the future security of staff employment in what even the management consultancy of the 1980s was willing to accept as a 'stable core' of employment, ABM will have consequences for the way in which staff functions are actually performed.

It has previously been argued (Armstrong and Tomes, 1996; Armstrong, in press) that regimes of accountability consist of languages which do more or less violence to activities to which they are applied (the aesthetic design of products was the example given). This is not just a question of the slippage between performance and performance indicator (activity and cost-driver in the case of $\mathrm{ABC}$ ); rather it is a question of the 
redefinition of performance itself, as it undergoes translation from the culture of the performer to that of the monitor. Translation is an inherently indeterminate act (Winch, 1970; Hollis, 1970), and this is exacerbated when it is animated by an hermeneutic of suspicion rather than one of understanding. This, it will be argued, is precisely the spirit in which ABM approaches the staff department. Instead of seeking to grasp the larger purpose behind its activities, ABM simply assumes that these activities are (and should be) separable repeated acts performed 'for' products or processes. Anything which does not fit into this framework is regarded as a prima facia candidate for the chop. Where ABM is 'successfully' implemented, this image of the staff function may become a selffulfilling prophecy in that it the department's activities may actually be reduced to routine technical or clerical services. The loss, to the extent that spokespersons for the staff functions are to be believed, will be the prospective value added through developments within the staff functions themselves, markets, human resources or, in the case discussed in this paper, the supply chain. The abolition of the staff department as an employment shelter, therefore, may have a downside, quite apart from its human cost. The case for $\mathrm{ABM}$, even as a means of boosting profitability, is far from convincing.

\section{Cost Allocation as Convention and as Reality}

Although it is not always obvious from practitioner expositions, the ABM project of opening up staff activity to senior management control depends on a fundamental reconceptualisation of the nature of indirect costs. The original objective was to correct the 'distortions' of single-based absorption costing, and it was on the promise of a gain in accuracy that $\mathrm{ABC}$ gained its initial purchase on managerial practice. In the process, the indirectness of indirect costs was newly perceived to be an illusion, caused by the complexity of the activities which 'really' connected them to products and processes. If this complexity could be adequately modelled in a practical cost control system, it would 
be possible to monitor and control staff activity exactly as had been achieved for shopfloor labour two generations earlier.

Both developments - the initial adoption of $\mathrm{ABC}$, and the possibility of its extension into a means of controlling staff labour - depended on a re-thinking of indirect costs. The context in which this first occurred, albeit implicitly, was the insistent claim that $\mathrm{ABC}$ is more accurate than absorption costing. Recent examples include Cooper (1990b), Roehm, Critchfield and Castellano (1992), Cooper et al (1992), Banker and Johnston (1993), Babad and Balachandran (1993), Borjesson (1994), Datar and Gupta (1994), Danilenko (1994), Letza and Gadd (1994), Lawson (1994), Marshall (1995), Adams (1996) and West et al (1996).

The more one reflects upon these claims, the stranger they appear. If the definition of indirect costs is taken seriously - as those which 'cannot be traced directly to cost objects' (Wilson and Chua, p. 82) - in what sense can one method of allocation be more accurate than another? If correct allocations cannot exist, even in principle, there can be no standard by which accuracy can be judged. Typically, the response of the activity costers is that of busy people who have no time for such conceptual niceties: they produce sample calculations which 'demonstrate' the greater accuracy of activity-based costing simply by showing that single-base absorption costing gives different result (e.g. Kaplan, 1987, p. 7.20; Innes and Mitchell, 1990, p. 14; Adams, 1996). That this simple-minded tactic appears to convince its protagonists points towards a fundamentalist mindset within which the relative merits of $\mathrm{ABC}$ and absorption costing are not really a matter for argumentation.

Underlying the controversies over the supposed accuracy of activity-based costing, there are uncertainties about the ontological status of allocated costs which fail to be articulated within the language of cost accounting practice. For the sake of exposition, let us take the 
ontological starting point of cost accounting to be one in which direct costs are real, in the sense that they are external to cost accounting as a practice ${ }^{4}$. That is, their calculation and their association with particular cost objects does not depend on the particular approach to costing which is adopted. The question then arises of whether or not allocated indirect costs are real in the same sense. Discussions of traditional absorption costing are mightily confused on this point.

If the definition of indirect costs quoted above is taken at all seriously, allocations of them can never be real. Because they vary according to the allocation base, the resulting allocated costs are matters for individual judgement constrained by professional convention. Ontologically, they are intellectual constructs. It follows that claims for them of greater or lesser accuracy, except in the 'internal' sense of computational correctness, are meaningless ${ }^{5}$.

The problem with this position is that costing claims to be a practical art. Whilst it may be possible to validate cost allocations within a closed universe of accounting convention, this cannot be the case with management decisions based upon them. Because the consequences of cost allocation must live in a world of managerial practice, accountants smuggle in claims of realism by the back door. It is one marked 'approximation'. Consider the following statement from Wilson and Chua (1993, p. 82):

'By definition, indirect costs cannot be traced directly to cost objects which will mean that the resulting full (or 'absorbed') cost is inaccurate to an unknown extent.'

The contradiction lurking within this statement lies in the fact that inaccuracy, even of unknown extent, implies that a true allocation of indirect costs is possible in principle. The same authors' definition of indirect costs, on the other hand, implies that it is not. It follows that the extent of the inaccuracy is unknowable (as well as unknown), in which 
case it is not inaccuracy at all, but a recognition that there is a difference between convention and knowledge. Wilson and Chua are clearly sensitive to this issue:

' . . . the real answer is both unknown and unknowable, given that there is no definitive basis for apportioning or absorbing indirect costs. However some bases are better than others.'

(Wilson and Chua, 1993, p. 107. Italics in original)

Thus the admission of inaccuracy obscures the practice of arbitrariness. Meanwhile, ‘inaccuracy’ - paradoxically enough - creates the possibility that allocations of indirect costs may be near enough to the 'truth' for practical people. From this point, it becomes possible to assert that some bases of cost allocation give better approximations than others, although the grounds on which such claims are made are necessarily left imprecise ('necessarily', because if clearly articulated they would, again, contradict the definition of indirect $\operatorname{costs}^{6}$ ). Having mooted the notion that there are variations in the appropriateness of allocation bases, Wilson and Chua arrive, a few pages later, at the familiar starting point of activity-based costing:

'And labour-based indirect costs rates continue to predominate in manufacturing industry, regardless of the evidence which shows that direct labour is an increasingly insignificant element of total cost, and thus an increasingly inappropriate base for recovering indirect costs. Any approximation of full cost that is built up from an indirect cost element based on direct labour is unlikely to be an acceptable approximation ... .

(Wilson and Chua, 1993, p. 109)

More sophisticated than most, Wilson and Chua's discussion is entirely typical of the manner in which the ontological basis of indirect cost allocation hovers between realism and idealism. It could be that these ambiguities are an evolved response to the social 
pressures upon cost accounting. As has been shown by Ernest Gellner (1970), the contradictions lurking within certain everyday concepts may serve important social functions. So it may be with cost allocation. On the one hand, the concept of approximation serves to legitimate the arbitrary allocation of costs as the only possibility in the face of an unknowable truth. On the other hand it asserts the informational value of these allocations. So it is that a gesture of faith, albeit one which has accumulated the patina of custom, masquerades as computational convenience.

Activity-based costing, at least in its core expositions, marks a decisive break from these ambiguities. Although the advocates of ABC continue to use the term 'indirect costs', they do not really believe in them. They sense, though they do not always clearly articulate, that all costs are, or should be, direct. Indeed ABC's best-known slogan: 'Activities cause costs and products consume activities' is nothing more than a working definition of the direct (labour) costs of production. As such it is at once an assertion of fact and a programme of action. If all costs are really direct, the task of (relevant) cost accounting is to uncover that directness. This is the classic realist enterprise. Underlying the complexities of empirical situations, it is believed that there are real relationships to be uncovered between product (or process) and (direct) cost ${ }^{7}$. ABC proposes to achieve this by identifying the real activities which contribute to the product and by computing the real (direct) cost of each. That this real relationship between product and cost may be very complex does not alter the fact that it is calculable in principle. And if this is the case, it becomes meaningful to apply the concept of accuracy to practical attempts to model it. Approximation here does not stand for arbitrariness: rather it is a matter of truncating the list of activities in the interests of computational simplicity, and of choosing cost drivers to proxy for them which are a compromise between representational accuracy and accessibility to measurement (e.g. Innes and Mitchell, 1990). 
In this manner, indirect costs are reconceptualised within $\mathrm{ABC}$ as the direct costs of real activities. It is this ontological foundation which underpins both the claims of superior accuracy made for $\mathrm{ABC}$ and the development of $\mathrm{ABM}$ as a means of evaluating and monitoring staff functions.

A first question which needs to be asked of the $\mathrm{ABC} / \mathrm{ABM}$ programme is how far it actually succeeds in recasting indirect costs as direct. This is a question of methodology, as well as ontology.

\section{The Concealment of Indirect Cost Allocations Within Activity Based Costing}

In practice, most applications of $\mathrm{ABC}$ make arbitrary allocations of common costs. The search for the activities which connect costs to products and processes, and for the cost drivers which proxy for them, needs to compromise between representational accuracy and manageability. The result is that some indirect costs - hopefully a small proportion of the total - are virtually bound to be excluded from the cost-pools associated with a practical set of cost drivers. Whether this is felt to be a consequence of their inherent indirectness, or merely of the complexity of their real connection to products and processes (and two views on this are considered on page 21), the consequence is that these costs are treated as common.

This much is openly acknowledged and there can be no quarrel with reasonable approximation in the cause of managerial practicality. The problem with the ABC/ABM project of recasting indirect costs as direct is not so much that it cannot be completed in practice but that many of the costs which are identified as the direct costs of activities are still infected with indirectness.

The procedure begins with a census of the activities which staff departments perform, usually for products and processes, though sometimes for customers or markets (e.g. Cooper et al, 1992, Ch. 5.) Each activity is then costed according to its occupancy of staff 
time and other resources. For clarity in the discussion which follows, the cost objects will be taken to be products and the costs to be traced to them will be assumed to be only those of staff time. Similar arguments would apply to other cost objects and to the allocation of the costs of equipment usage.

The costing of activities according to their consumption of staff time means that the staff department is treated as a mass producer of activities for whom all labour costs are direct. Computationally speaking, this is similar to the charge-out systems used for cost recovery by self-employed professionals and, in some companies, as a means of exposing staff departments to external competition (Johnson, 1988). Charge-outs, however, explicitly recognise the allocation of indirect costs. The procedure for costing activities in $\mathrm{ABC}$ on the other hand, forces the staff manager to account for all - or most - of the staff hours as direct labour ${ }^{8}$. The result will be that any labour time which is 'really' indirect in relation to the defined activities will be judgementally allocated by the manager to one or another of these activities, as a means of coping with the imposed form of accountability. In consequence the apparent direct costs of the activities identified in the process of $\mathrm{ABC}$ implementation will contain concealed allocations of indirect labour costs. The question of the superior accuracy of $\mathrm{ABC}$ as compared to absorption costing then hinges on the proportion of these concealed indirect costs relative to the whole. The greater the proportion of true direct costs, i.e. nearer the staff department is to a labour-onlysubcontractor, the more convincing will be the case for the accuracy of ABC. Conversely, the more the department resembles a solicitor's office, where the common costs of nonspecific research are charged out on a direct labour basis, the less realism can be claimed for activity costs. To put the matter another way, the more of the labour within a staff department which is indirect in terms of its output activities, the greater will be the proportion of arbitrarily allocation within activity costs. 
How great is this proportion likely to be in practice? A difficulty here lies in an imprecision within the notion of direct cost, or, what is equivalent, in the idea that costs are 'caused' by particular events or activities (Piper and Whalley, 1990). Consider a favourite example of the advocates of $\mathrm{ABC}$, that of placing a purchase order. Only a small fraction of the staff time attributed to this activity by the departmental manager will be taken up with actually writing out and dispatching the order. A larger proportion will be taken up with extracting information from the department's stock of information so that the order can be made, whilst the rest will be consumed in updating that stock of information in the light of the order. Details of the purchase will need to be recorded, for example, so that the incoming goods and the invoice can be checked against them. If the procedures for doing so are well-designed, the activity of 'checking goods inwards' will be simple and cheap. If, on the other hand, the records are inaccessible, or otherwise userunfriendly, 'checking goods inwards' will appear time-consuming and expensive. Most of the activities of a bureaucratically organised department will be similarly interdependent in that they both draw upon information deposited in the course of previous activities and involve the deposition of information needed for future activities. In cost terms, the activities are connected by a network of cross-subsidies so that the separation of costs between them becomes arbitrary. To the extent that staff departments approximate to this model, the costs of record-maintenance will account for most of the total, and should be treated as common.

Where this is the case, treating the cost of the staff time devoted to an activity as its real (direct) cost, really amounts to a re-allocation of the common costs of record maintenance on the assumption that each activity should bear a quantum of this cost exactly equal to that which it consumes. It is assumed, in effect, that activities which contribute a lot to record-keeping also depend on a lot of record-keeping, that there are no activities which depend on a lot of paper work but do not themselves involve very much. 
Where these allocated common costs are a substantial proportion of the whole, ABC may fail to model the behaviour of the costs of staff departments when products are dropped or redesigned so as to reduce their consumption of particular activities. Noreen's (1991) analysis demonstrates that the correct modelling of costs in such circumstances requires that the costs in each cost pool should depend on a single activity, a condition which is clearly violated where the 'direct' cost of each activity includes the cost of maintaining the stock of information required for other activities.

These considerations reflect badly on Argyris and Kaplan's (1994) claim that ABC is now established as an internally consistent technical theory. Whilst there may be staff departments in which all costs are the direct costs of their activities, this cannot be the general case. It follows that the project of reworking all or most of the costs of staff departments as the direct costs of production (or of servicing markets or customers) is flawed by the presence of concealed allocations of indirect costs within ABC. Also eroded is the ground on which stands the claim that $\mathrm{ABC}$ is more accurate than other methods of cost allocation. To the extent that the costs of activities are not, after all, direct costs, there is no reason to suppose that the allocation procedure by which they are determined is 'more accurate' than any other.

The validity of the truth claims made for $\mathrm{ABC}$ is one thing; its social consequences are another. As the sociologist W.I. Thomas pointed out some time ago (1957, p. 42), people do not act according to the situation but according to their definition of it. So has been with belief in the reality of activity-based costings. It is this belief which defines the difference between activity-based and absorption costing, not differences in computation. Numerically, of course, (putatively real) activity based cost allocations can be reproduced exactly in the form of (avowedly conventional) multiple-based absorption costings. Only the rhetorical framing differs - a fact which has led some commentators to the conclusion that there is no essential difference between $\mathrm{ABC}$ and multiple base absorption costing 
(e.g. Noreen, 1991; Kennedy, 1995). The rhetoric, however, is precisely the point. The cardinal virtue claimed for activity-based costing is that its allocation of costs is real. This reality depends not only on the reality claimed for the costs of the activities (discussed above), but also upon the claim that the activities through which they are distributed are those actually performed for the production process (or for customers or markets). This realist ontology was crucial to the development of $\mathrm{ABC}$ into activity-based management.

\section{From Cost Allocation to Activity-Based Management}

So long as product costing constituted the whole of the ABC agenda, its ontology bore only on the question of its accuracy. The revelation that all costs were really direct, however, opened up a whole new project of organisational control for the advocates of ABC. If the activities identified in the course of implementing the product costing system were real rather than notional bases of allocation, it became thinkable to control staff departments in terms of these same activities. If, in the production-centred world-view which begat $\mathrm{ABC}$, 'Products consume activities', it made sense to manage staff departments, and perhaps the entire organisation, in terms of these activities. Thus:

'Activity-based management is the management and control of enterprise performance using activity-based information as the primary means of decision support.'

(Hixon, 1995)

It was on the basis of its realist ontology, therefore, that $A B C$ evolved ABM. In the process, the cost-drivers originally devised as a means of allocating indirect costs were pressed into service as non-financial performance indicators for staff departments (Morrow and Hazell, 1992; Cooper et al, 1993; Hobdy, Thompson and Sharman, 1994; Clarke, 1994; Clarke and Bellis-Jones, 1996; Aird, 1996; Lindahl, 1997). Although the intellectual and political origins of $\mathrm{ABC}$ were very different from those of 'accountable 
management' in public sector services (Humphrey, Miller and Scapens, 1993), its basic technology of control is a series of non-financial indicators of performance similar in principle to those currently being promoted in the public sector (see, for example, Cochrane, 1993; Gray and Jenkins, 1993; Ezzamel and Willmott, 1993; Laughlin, Broadbent and Willig-Atherton, 1994; Lawrence, Manzurul and Lowe, 1994: Chua and Preston, 1994; Ogden, 1995). Both developments, moreover, were propelled by a kind of organisational asceticism, pre-occupied with the elimination of activities which failed to add 'customer value', and with minimising the unit costs of those which did.

The difference in the contexts, however, is important: where the public demand for services such as education and health is highly elastic, that for staff services within a capitalist enterprise is not. Evidence from companies which have installed ABC systems indicates that the enthusiasm of manufacturing managers has much to do with the prospect of reducing the burden of overhead and little to do with enhancing the quality of service (Pattison and Gavan, 1994). Where the indices of public service performance allow, in principle at least, for expenditures aimed at increasing the quality of output, the superficially similar indices applied to service departments within private companies function more like expenditure caps. This means that ABM is really nothing more than an updated and partially automated form of cost reduction and control.

The potency of ABM in this respect is considerably amplified when it is mated with 'value analysis', a procedure animated by the belief that it is possible to make some determination of the value added by particular activities (Adams, 1996). The basis on which this is done is quite obscure ${ }^{9}$, and may have much to do with the prejudices of those making the determination. In one of the case studies by Cooper et al (1992) only two of the seven activities identified in an 'Accounts Payable' section ( $40 \%$ of staff time) were accepted as representing the actual business of processing accounts (1992, p. 141-2). The rest, including the $35 \%$ of staff time taken up with 'process management' were not. 
A leader of the $\mathrm{ABC}$ implementation team spelt out the implications for future staffing levels: 'The accounts payable data revealed how expensive we were. I see now how we can use this information to reduce the cost of processing an invoice.'

In general, $\mathrm{ABC}$ produces, as a by-product, a list of staff activities which is handy for the purpose of value analysis. Since 'low value-added' can mean little else but 'dispensable', it is fairly obvious that it is primarily a means targeting staff reductions (See, for example, Cooper et al, 1992, Ch. 7; Sephton and Ward, 1990; Steimer, 1990). Given this, it is scarcely surprising that 'value-added' tends to become the oval ball in an organisational scrimmage around the theme of usefulness. In some of the $A B C$ implementations reported by Cooper et al (1992), attempts to rank activities according to their value added were described as 'controversial' or 'painful' because 'Everyone had a different definition of what's valuable to them.' Cooper et al (1992, p. 72). It was considered 'surprising' that the staff managers in one implementation considered only $4 \%$ of their own department's activities to be of 'low value' (Cooper et al, p. 138), an outcome which indicated to the implementation team that steps should be taken to ensure that in future value would be judged from the point of view of the corporation as a whole.

( New Para) The identification of indirect costs with activities in ABC also exposes their potential for variability in ABM. If the consumption of activities varies, either as a result of market fluctuations or as a consequence of purposive changes in procedure or product redesign, so, also, should the cost of performing them (Morrow and Connolly, 1991). The unit costs of activities, or rather, of their surrogate cost-drivers, become, in effect, standard costs which open up the black box of the staff department, just as Scientific Management and standard costing once broke open the black box of craft production (Braverman, 1974, Miller and O’Leary, 1987). This new regime of accountability exposes the staff department to precisely the same insecurities and pressures for labour intensification as manufacturing (e.g. Pattison and Gavan, 1994, Hobdy, Thompson and 
Sharman, 1994) ${ }^{10}$. The destruction of the staff department as an employment shelter is not an unintended consequence of $\mathrm{ABM}$; it is precisely the point, and there are signs that those on the receiving end are becoming aware of it. Dugdale (1990) has reported that some $\mathrm{ABC}$ implementations have only been allowed to proceed on condition that employment would be preserved.

Despite their formal similarities as monitoring systems, there are important differences between the terms on which $\mathrm{ABM}$ proposes to open up the labour process as compared with Scientific Management and standard costing. Where Scientific Management involved a concrete simplification and standardisation of production processes, ABM offers no positive guide to the revision of working practices. Its 'standard costs' are not those of activities which have actually been redesigned in standardised form. Rather, they are the expression of a belief that staff activities already are, or should be, of this form. Despite attempts to represent $\mathrm{ABM}$ as an instrument of quality management (Steimer, 1990, Armitage and Russell 1993, Letza and Gadd, K 1994, Thomas and Mackey, 1994; Clarke and Bellis-Jones, 1996), the most it can actually achieve is rescaling of existing activities, not a modification of them.

\section{The Scope of $A B C / A B M$}

The potential for ABM to influence the performance of staff functions is proportional to the claims made for its scope. In general, it is the more creative, least routine staff activities, those which least fit its framework of accountability, which are under most threat. It is not inevitable, however, that ABM should be viewed as a comprehensive approach. In the related debates on the scope of ABC, there is a considerable body of opinion which accepts that there are activities which cannot, and perhaps should not, be traced to particular cost objects.

The programme of the 'comprehensive' view of ABC was set out by Kaplan in 1987 (Kaplan, 1987, p. 7.27). 'The scope of the product cost system is the entire value chain. 
All of the costs of the organisation are included in product costs.' Similarly Johnson (1988); 'In principle, all activities in an organisation supply output to meet customer's demands.' This inclusive view of $\mathrm{ABC}$ is operationalised in the interrogation procedure recommended by Innes and Mitchell (1990, p. 8.): 'When the work-time of all of the staff is fully accounted for, it is reasonably certain that the activity listing is comprehensive.'

By 1988, however, Kaplan had reconsidered, suggesting that the costs of unused capacity should be excluded on the grounds that these are period expenses and that those of research and development should be treated as an investment in the future of the enterprise as a whole (Kaplan, 1988: 65). Other arguments against the 'inclusive' view are that there are costs which cannot be identified with particular activities (Staubus, 1990), that it is cannot be meaningful to allocate costs down to product level when they are not controllable at that level (Sephton and Ward, 1990), and that cost behaviour will not be correctly modelled by ABC systems when the cost pools include the fixed costs of maintaining a capability (Noreen, 1991).

In practice, the difference between these positions is not as extreme as the polarisation of their arguments suggests. Those who believe that $\mathrm{ABC}$ ought to form a comprehensive system of cost allocation are quite prepared to make arbitrary allocations of costs which prove difficult to trace to particular objects. In Innes and Mitchell's illustration of the allocation of purchasing costs, for example, the costs of supervision are distributed equally to all activities (Innes and Mitchell, 1990, p. 9).

For $\mathrm{ABC}$, the issue of scope may be a minor one in any case, since it concerns only that proportion of indirect costs which is difficult to identify with accessible drivers. From the point of view of cost allocation, it makes little difference whether small proportions of indirect cost are allocated through approximate cost drivers, whether they are recognised as period costs and allocated arbitrarily or whether they are not allocated at all. When the 
cost drivers of $\mathrm{ABC}$ are regarded as performance indicators, as in $\mathrm{ABM}$, the consequences may be more serious. To the extent that particular cost drivers fail to capture the meaning of staff activity, they create pressures to misdirect that activity, and the costs of doing so may be out of all proportion to expenditure involved.

In contrast to the debates on the scope of $\mathrm{ABC}$, few, if any, discussions of ABM have confronted the issue of whether or not there are limits to its applicability. On the contrary, the tendency of management consultants has been to talk up its potential as a comprehensive approach to the management of staff functions at all levels. Typical is the following definition from the leaders of Ernst and Young's specialist ABM consultancy $^{11}$ :

'[ABM is] A way in which an organisation can direct, measure and control its aim for enhanced performance. This is achieved by the creation and use of an activity-based performance measurement framework as the primary means of resource management, continuous improvement and decision-making.'

(Evans and Ashworth, 1995)

If this means what it says, the implication is that divisional and corporate-level staff functions as well as the support services at level of the operating site are candidates for the ABM treatment.

\section{The Reduction of Purpose to Activity}

The methods by which the activity outputs of staff services are to be established appear, at first sight, to be both reasonable and participative. The usual procedure begins with an interview with the manager concerned (Cooper, 1990a; Cooper et al, 1992: 16; Innes and Mitchell, 1990, p. 8). Multidisciplinary teams which include, but are not necessarily dominated by, management accountants ask managers to list the activities which they perform for products and processes, to estimate the proportion of staff time and other 
resources expended on each activity and to agree a cost-driver which will stand for a unit performance of it. Interviews of this kind are said to be both quick and cheap, taking between 30 minutes and two hours per manager (Cooper et al, 1992, p. 16).

In reality, participation on these terms invites staff managers to collude in a very particular view of their own functions. As a method of cost allocation, ABC can only work by reducing the work of staff departments to a set of separable activities - separable because each must have an identifiable cost. When such a view is carried forward into ABM, the staff department is seen as the producer of repeated acts of service, usually for production, each of which gives off a countable signal (as, for example, the ordering of material is signified by a form). Such an atomised view of the staff function is virtually guaranteed to miss the point. It completely ignores the question of whether there ought to be some larger purpose behind the activities, and whether it might be more appropriate to hold the department accountable in terms of this purpose. As has already been recognised within the literature of $\mathrm{ABC}$, one effect of this substitution of activity for purpose is to encourage 'gaming behaviour' or 'goal-displacement' (Merton, 1940). Enmeshed in performance monitoring systems which prioritise the ratio of activity outputs to cost, managers find ways of doing their bit which have nothing at all to do with either efficiency or effectiveness. Innes and Mitchell (1990, p. 26) give the example of splitting purchases into smaller batches so as to increase the number of purchase orders 'produced'.

However reasonable it may appear to the productivist mind-set, not all of staff activity can be reduced to routine services performed for other functions. By threatening to reduce expenditure to levels which can be justified in such terms ABM threatens to deny space for developmental activities indigenous to the staff department. To take concrete cases, the concepts of policy and strategy as applied to human resource management and purchasing will, according to their advocates, create company capabilities, exactly as 
R\&D creates the potential for new products (e.g. Tyson, 1985; Saunders, 1997). Recall too that Kaplan (1988, p. 65) advocated the exemption of R\&D expenses from allocation on the grounds that it is an investment in future products, not a cost of present products. The same argument could equally apply to the recruitment and training of effective personnel, or to the development of the supply chain. The problem with ABM is that it is programmed to deny and annihilate anything which is not on its list of routine activities, whether it is of genuine value or not.

The irony is that the diffusion of $\mathrm{ABC} / \mathrm{ABM}$ appears to be hampered by exactly the mentality which it seeks to operationalise in the form of accounting controls. Line and senior managers tend to regard accounting as a service providing routine (and not very useful) information to other functions (Lyne and Freidman, 1996). As a consequence accounting departments were run down during the 1980s, so that a major obstacle to the development of improved costing systems is now the lack of staff time (Innes, Mitchell and Cobb, 1992, p. 9). Would there, one wonders, be time in an accounting department which was itself subjected to ABM?

Despite its potential for de-manning, ABM's fixation on activities, paradoxically, threatens to fetishise existing routines. Providing staff managers succeed in establishing activities as valid during the interview phase, and in shepherding them through the cull of value analysis, these activities, or rather their cost-drivers, are likely to become fossilised within the activity monitoring system, especially when this is written into software. It is all very well for management consultants to argue that ABM should 'describe, regularly and in detail, what the organisation does' (Evans and Ashworth, 1995, italics added), but one of the problems with $\mathrm{ABM}$ is that it is expensive in staff time to install (Innes, Mitchell, and Cobb, 1992). By the same token, it will be expensive to update. The consequence may be an anchylosis of the organisation's existing bureaucratic and technical procedures in which the apparent concreteness of 'products consume activities' 
conceals the fact that they do so as a consequence of managerial decisions (e.g. maintenance routines, purchasing procedures). The incorporation of these decisions into a system of activity-based management actively discourages reviewing them. Whilst ABM facilitates the management of activities, in the sense of exerting pressure on the resources devoted to them, it discourages activity management in the sense of searching for better ways of accomplishing their purpose. In any case, such a search would (again) create costs which would be difficult to justify within the ABM framework.

If the foregoing is true, one would expect some show of resistance from staff subjected to the ABM frame of reference. Reports of the staff view of things, it has to be said, are not a frequent feature of implementation case studies. Many of these lack ethnographic detail and they tend, in any case, to be written up by consultants and/or an implementation team, chosen for their prior commitment to the ABM project (e.g. Bhimani and Pigott, 1992). Generally the voices of the subjects are suppressed. It is well established, however, that successful implementation of $\mathrm{ABC} / \mathrm{ABM}$ depends on the prior commitment of senior management (Shields, 1995; Adams, 1996), accompanied by a fair amount of pressure. The recommendation of Lammert and Ehrsam (1987) on this point is an 'intense program of education and training.' accompanied by the linkages of bonuses to the new performance measurement system (see also Argyris and Kaplan, 1994). This expenditure of effort on re-education can only mean that passive resistance on the part of some of those affected is the norm rather than the exception. There are, in addition, some direct reports of failures of enthusiasm. This is variously attributed to the implications for staffing levels (Pattison, and Gavan, 1994), adverse effects on incentive payments (Lammert and Ehrsam 1987) or the embarrassment and threat experienced by managers whose products or practices are newly revealed as unprofitable (Lammert and Ehrsam 1987; Shields and Young, 1989; Argyris and Kaplan, 1994). Occasionally resistance to 
ABM is stripped of its rationality altogether and dropped into a conceptual black hole marked ‘resistance to change’ (e.g. Cooper et al, 1992, p. 324).

Unusually, the staff managers speak in one of the case studies by Cooper et al, (1992, p. 133):

'Our office environment is difficult to quantify, tasks are less repetitive, and fewer data are collected, than on the typical shopfloor of a manufacturer.'

It could be that the main evidence of staff resistance to the conceptual framework imposed upon staff activities is indirect. Horngren (1990), for example, reports the failure of an $\mathrm{ABC}$ implementation in a high-technology company, due to a preponderance of costs which could not be traced to products. It needs to be remembered that there is an irreducible social element in the construction of ABM systems and 'could not' in this case is likely to express the outcome of a negotiation between the implementation team and the staff managers concerned.

According to Innes, Mitchell, and Cobb (1992) it is common to find that the initial list of activities obtained from staff managers is too extensive to fit into a feasible system, whilst Pattison and Gavan (1994) report that there have been failures of implementation due to an over-proliferation of activities and cost drivers. Whilst this over-proliferation could be exactly what it appears - variety in repetitive acts of service - it could also be symptomatic of an attempt on the part of staff managers to insist on the organic complexity of their tasks within a frame of reference which insists that these are made up of discrete acts of service. Where there is resistance of this kind, the typical implementation may involve the negotiation of a compromise around the notion of approximation. To the implementation team, the final list of activities and their cost drivers is approximate because it is abbreviated. To staff managers it could be 
approximate in the sense that much of the meaning of their work has escaped the model altogether.

The Degradation of Staff Functions: Prototypical Purchasing

The previous section has argued that ABM proposes a degradation of other staff functions. This thesis will now be illustrated on one of the chosen grounds of ABC: that of the purchasing function. For some reason $\mathrm{ABC}$ gurus have it in for the purchasing department:

'It should not cost us much more to order a $\$ 10,000$ dollar part than a $\$ 10$ dollar part. Typing the extra zeros on the check is not very expensive. Why [should] procurement dollars increase with dollars of material purchased.'

(Kaplan, 1987: 7:12)

Recent expositions of the application of ABC/ABM to purchasing include those of Jeans and Morrow (1989), Innes and Mitchell (1990), Roehm, Critchfield, and Castellano, (1992) and Pattison and Gavan (1994).

The procedure will be to compare the account of purchasing given in recent textbooks on the subject with its representation in activity-based management. The potential biases in both accounts need to be borne in mind. Purchasing enthusiasts are just as likely to produce expansionary accounts of their field of study as $\mathrm{ABC}$ advocates are to reduce it to terms with which they can cope.

\section{Purchasing: Adding Value Through the Management of the Supply Chain}

In recent expositions, purchasing is reinvented as 'Strategic purchasing and supply chain management' (Saunders, 1997). The name says much. 'Supply chain' is evidently a conceptual expansion of the workaday 'supplier', 'management' stakes out a claims to executive decision-making and the prefix 'strategic', as with management accounting, 
suggests that the function needs to be represented at board level. In other words, we are looking at a managerial profession on the make (Armstrong, 1994).

In support of these claims purchasing has developed a 'rhetoric of urgency' which parallels, in many respects, that of management accounting (see page 5). There is the same invocation of competition from the Far East, coupled with the same threats of loss of competitiveness if the function is not accorded its due importance :

'[There is a] huge gap in performance between the best performers in Japan and the others elsewhere in the world ... Purchasing and supply chain management practices have played a part in the superiority of these companies and they need to be emulated by others as they try to catch up.'

(Saunders, 1997, p. 308)

There are even parallels with the case made for $\mathrm{ABC}$ in the references to changes in the cost structure of the modern corporation. Where $\mathrm{ABC}$ advocates make much of the increasing proportion of costs now accounted for by fixed overhead, the case for increasing the emphasis on supply chain management is argued, in part, from the rising proportion of total costs accounted for by purchasing decisions (Gadde and Håkansson, 1993, p. 4).

The animating insight behind the supply chain management approach is that the lowestprice supplier may not be the lowest cost supplier. There is a 'revenue improvement' term '[Which] means suppliers provide additional services such as product design and development' (Saunders, 1997, p. 307) so adding value to the final product and reducing internal costs such as inspection and handling (see also Gadde and Håkansson, 1993, p. $165,172 \mathrm{ff}$.). In order to realise these benefits, the role of the purchasing function needs to be expanded to include the management of these development programmes and the supplier-customer relationship in general. 
There is, unfortunately, much to be done. 'In many companies, purchasing suffers from low status.' (Gadde and Håkansson, 1993, p. 31), a problem it appears to have in common with management accounting (Lyne and Freidman, 1996). Most managing directors, it seems, 'remain stunningly oblivious to the benefits which effective practice can bring.' whilst '... senior managers outside the function need to alter their perception of the scope and potential of purchasing and supply chain management' ' (Saunders, 1997, p. 310311).

Saunders' prescription for repositioning the purchasing function begins with its representation of at board level, so that supply strategies can be integrated into company strategy as a whole. It also calls for an expansion of the function and the development of its staff, not only so that the supply chain can be adequately managed, but also so that its developmental possibilities can be integrated into other management decisions.

\section{The Purchasing Function According to ABC}

Like Saunders' Strategic purchasing and supply chain management (1997), Innes and Mitchell's Activity-Based Costing (1990) was published by the relevant Chartered Institute. To that extent it can be taken to be acceptable as an exposition of $\mathrm{ABC}$ to the Chartered Institute of Management Accountants. Like many textbooks, it uses purchasing as an illustrative example of how the costs of a 'support function' might be allocated using ABC methods.

The first step is to produce a list of activities performed by the function. Innes and Mitchell observe that in most existing applications of ABC, management accountants have drawn up this list in consultation with the department manager. They are careful to emphasis this participative aspect: 'It is important that the department manager (given his (sic) local knowledge) and not the management accountant selects the relevant activities.' In order to assist the department manager in this task, they suggest that 'A useful 
approach at this stage is to question the manager on the purpose for having each member of staff.' A little later, they amplify the kind of questions which might be asked:

- Why do you need more than one person on this activity?

- Under what circumstances would more staff be required on this activity?

- Under what circumstances could staffing be reduced on this activity?

- Why is overtime worked on this activity?

- Why does idle time occur on this activity?

If this sounds a little aggressive, consider the following Socratic dialogue on the same point offered by Kaplan (1987: 7:18):

'Do not believe someone who says "We have 11 people in this department, but it is a fixed cost.” Ask why this function cannot be handled with one person. He says, "We cannot do it with one.” Why not? "Because there is too much work for one person to do by herself." Aha, now comes the important question, "What kind of work?” Find out what creates work for the department that one person cannot do, that requires 11 people to do.”

One is left to imagine what goes through the minds of staff managers when they are interrogated in such a manner by an inquisition of accountants and managers from other functions. If this is participation, it is participation on terms very much defined by the questioning process. This insists that the agreed activities must account for the whole of staff time and equipment usage (Innes and Mitchell, 1990, p. 8 ). What counts as an activity, moreover is defined in a very particular way. Firstly activities must be relatively homogenous repeated acts. Secondly, and recalling that purchasing has been defined as a 'support function', activities must be performed 'for' another function, usually manufacturing ${ }^{12}$. A meeting to consider purchasing strategy, for example, would fail to qualify as an activity on both counts. The list of activities which emerges from the 
consultation process, therefore, is a picture of the purchasing function which is decisively shaped by the core assumption behind the questions: that all of the staff time and equipment usage in a service department ought to be taken up with routine activities performed for other departments.

Innes and Mitchell's illustrative table of activities for a purchasing department, and their associated cost drivers is reproduced in Table 1 (minus the notional figures for the resources expended on each activity, and their cost).

Table 1

\begin{tabular}{|ll} 
ACTIVITY & COST DRIVERS \\
The receipt of purchase requests & No. of requests \\
Vetting alternative suppliers & No. of supplier orders \\
& No. of suppliers \\
& No. of new parts \\
Ordering items & No. of supplier orders \\
& No. of items \\
& No. of suppliers \\
Expediting delivery & No. of deliveries \\
The approval of payment & No. of deliveries \\
Supervision & All of above drivers
\end{tabular}

Having produced a list of activities and their cost drivers, the next step is to produce a unit cost for each driver by dividing the total cost of the activities associated with it by the number of its occurrences. The whole of the costs of the purchasing department can then be assigned to products (or processes) by multiplying this unit cost by the number of costdriver occurrences associated with each product (or process). In this manner, the procedure expresses, now in calculative form, the assumption with which it began: that all of the costs within the purchasing department (with the exception of supervision, in Innes and Mitchell's example) are, or ought to be, the direct costs of its activities, either of labour or equipment usage. 
Innes and Mitchell (1990) present their notional treatment of purchasing purely as an exercise in cost allocation. Left at that, it would have no immediate consequences for the way in which the function is actually managed. Later, however, they argue the case for managing on the basis of activity-based cost information, although the argument is made in general terms rather with reference to their notional purchasing department. Thus: 'Management is facilitated through the selection of activity based cost drivers for each cost pool which (a) provide a set of activity volume based non-financial measures of performance which can provide useful routine feedback on process efficiency; (b) help in the identification of activities which are non-volume added and/or waste resources;. . . . (Innes and Mitchell, 1990, p. 21).

Referring to their table of purchasing activities, it is clear that this amounts to managing the department as if it were nothing more than a mass-producer of requests, vettings, orderings, expeditings and payment approvals. It is further assumed that the efficiency with which each activity is carried out can usefully be monitored by comparing its current unit cost against a set of established standards. It also implies that activities which are not associated with the defined cost drivers should be considered for elimination as superfluities.

Clearly these activity-based indices of efficiency are not even capable of indicating the effectiveness with which the purchasing function carries out its traditional role of securing supplies at minimum cost. Also completely ignored are the function's performance in co-ordinating with other functions, policy development and planning and forecasting, all of which are extensively discussed in Baily and Farmer (1990). The contrast between the $\mathrm{ABC}$ image of purchasing and the supply chain management approach is even more stark. Joint developmental work undertaken with the suppliers of materials or components in order to reduce the internal costs of assembly, inspection or 
handling, for example, is quite simply beyond its conceptual horizon. More, since none of these activities are likely to trigger occurrences of the cost drivers identified in an $\mathrm{ABC}$ exercise, any expenditure upon them will tend to be regarded as non-value added. In this manner, the application of ABM to purchasing would create pressures against any attempt to add value through the development of the supply chain.

\section{Measuring Purchasing Performance}

A striking feature the $\mathrm{ABC} / \mathrm{ABM}$ treatments of the purchasing function, is that they are written as if management accountants were the first to consider the question of measuring its performance. Yet the matter is considered at length even in Baily and Farmer's traditional treatment of the subject (1990). The following might be read as a comment on the kind of activity measures proposed by ABM:

'In purchasing, the calculation of the number of requisitions dealt with by a buyer in one day may tell us something about his (sic) efficiency in passing paper. The number of items received on time and the number of items which fail to meet the specification will, also, be of benefit in that regard. However, his (sic) effectiveness may be more concerned with establishing vendors who have the potential to supply for many years to come - competitively. Also with, e.g., reducing the number of these suppliers so that co-makership and just-in-time approaches may be managed to the best effect.'

(Baily and Farmer, 1990, p. 295)

Since this was written, the techniques of measuring purchasing performance have moved forward, with developments aimed at modelling some of the benefits of supply chain management. The key concept is that of the 'Total costs of ownership' (TCO). The idea is to trace all of the costs of processing materials or components (storage, handling, inspection, returns, re-working etc.) to each supplier so that the benefits of using a higher- 
quality supplier can be offset against the higher cost (Burt, Norquist and Anklesaria, 1990; Cavatino, 1992; Carr and Ittner, 1992; Ellram and Siferd, 1993; Ellram, 1993; Ellram and Maltz, 1995; Smytka and Clemens, 1995)

Of course this does not capture the whole of the benefits claimed for the supply chain approach. Like ABC, TCO is simply a form of cost allocation, and, as such, cannot place a value on any positive synergies from joint supplier-customer developmental programmes. Despite this limitation, it remains interesting that the development - which is essentially one in management accounting - has largely been driven by purchasing thinkers and practitioners rather than management accountants. Of the 11 case studies of the approach reported by Ellram (1995) only 3 involved the accounting finance function at all and only in one case was it the prime mover. In 10 out of 11 of the cases, moreover, the information used for the TCO implementation was captured outside the firm's normal accounting systems.

In view of this, and because the TCO approach is relatively recent, it is perhaps understandable that the purchasing applications of $\mathrm{ABC} / \mathrm{ABM}$ so far reported have failed to engage with $\mathrm{it}^{13 .}$ More striking, is their failure even to consider that there might be a 'purchasing view' of what its functions ought to be and how the performance of these might be measured. Since the low-level routine image of purchasing on which $\mathrm{ABC} / \mathrm{ABM}$ so much depends might have difficulty in surviving such an encounter, it could be that the integrity of the $\mathrm{ABC} / \mathrm{ABM}$ approach depends upon this kind of failure of awareness.

\section{Conclusion}

The relevance 'regained' in $\mathrm{ABC}$ was really an operationalisation in costing form of a productivist view of staff activities: that their main justification lies in their contribution to company outputs. It was this quasi moral view of the functional interdependencies within the corporation which underlay the distribution of staff costs to products and 
process according to their consumption of staff activities. In order to build this basis of cost allocation into a practical system, it had to be assumed that staff activities are standardised and countable acts, a view which was probably congenial to the productivist mindset in any case.

Both the technical apparatus and the world-view of $\mathrm{ABC}$ carried into $\mathrm{ABM}$. If the value of staff activity lay in its contribution to products and processes, it followed that staff departments ought be accountable in terms of that contribution and that staff costs should be controlled according to it. The activities identified by ABC offered a technology for achieving both, since they were claimed to be the real functional connection between the staff department and company outputs, not just conventional bases of cost allocation. In this respect, the realist ontology of $\mathrm{ABC}$ was crucial to the development of ABM. It meant that the staff activities initially identified for the purpose of cost allocation could pressed into service as performance indicators. Standard costs for these activities could be established and used as the basis for budgetary planning and control. In this manner the technology of ABM could connect with long-standing concerns over the lack of accountability within staff departments and the continued escalation of staff costs.

For the consultancies now engaged in the promotion of $\mathrm{ABM}$, its consequences for employment insecurity may not be an issue. Accountability in terms of a newly visible connection between staff activities and company outputs implies the short-run variability of payroll costs, is precisely the point, and is nothing more than manufacturing departments have experienced for several generations. If ABM threatens to 'go and ruin more life in the plush offices of support staff' (to quote a reviewer of an earlier version of this paper), that is no problem at all. That this may be achieved at the cost of degrading the performance of staff functions may cause more concern. 
The problem originates in the concept of activity on which both $\mathrm{ABC}$ and $\mathrm{ABM}$ are founded. Neither can function unless an activity is defined as a routine act performed 'for' the cost-object. Whilst certain services approximate to this pattern, it is clearly flawed and myopic as a total view of the work of staff departments. Strategic developments in the supply chain, in human resources, in marketing capability - and even in management accounting - may all be important to the long-run profitability of the capitalist enterprise. None of them, however, would qualify as activities as the term is defined within $\mathrm{ABC}$ and $\mathrm{ABM}$. Although the staff functions of the modern corporation are as susceptible as any other human activity to pretentious inflation in the cause of individual and group self interest, it would be hard to find a successful company which consists solely of a core function backed up by routine services. Yet this is the picture assumed in ABM.

The threat posed by ABM to the functionality of the staff department is illustrated by the contrast between the treatment of the purchasing function in modern textbooks and that in expositions of $\mathrm{ABC} / \mathrm{ABM}$. If anything, this is a ground of comparison which should favour the activity-based approach since the purchasing application has become a favourite illustration of its potential. The differences are striking. Where purchasing textbooks emphasise the potential for adding value through the such activities as coordinating supply and production schedules and joint customer- supplier development programmes, the ABM approach is fixated on the cost-efficient performance of routine services. Whilst some of the claims made for 'supply chain management' may well be inflated, and whilst there may be a gulf between purchasing prescription and practice, it is hard, in the light of this comparison, to see the ABM approach as anything other than tunnel-vision cost-cutting. Because its conception of activities cannot encompass the nonroutine work involved in the management of the supply chain - still less the work involved in developing the capability for doing so - ABM, where it is implemented, may 
succeed in imposing budgetary restrictions on the purchasing function which reduce it to the routine service stereotype assumed at the outset. In this aspect, it could be argued against $\mathrm{ABM}$ that it makes short-termism respectable, a conclusion which is truly ironic in view of Johnson and Kaplan's (1987) strictures against the short-termism encouraged by 'management by the numbers. ${ }^{14}$

\section{Endnotes}

${ }^{1}$ The time-scale of these developments varies enormously from company to company. On the one hand companies such as Renold Chains were experimenting with standard cost systems before the First World war (Bougen, 1989). On the other hand, some prominent UK motors companies were still operating in ignorance of their unit labour costs as late as the 1970s (Armstrong, 1989)

${ }^{2}$ When practiced by Japanese managers, apparently, direct labour-based absorption costing posesses the important virtue of encouraging automation (Hiromoto, 1988; Dugdale, 1990). In the USA, on the other hand, it merely fosters a form of financial gamesmanship in which reductions in direct labour are made for the purpose of redirecting overhead elsewhere in the company (Johnson and Kaplan, 1987).

${ }^{3}$ In much of this paper, ABC and ABM are written about as if they were active subjects. This is simply a shorthand for such usages such as 'the advocates of ABC' which would become awkward with repetition. It should not be read as an attempt to reify either technique as a social agent (cf. Mouzelis, 1995, p. 15) although a good case could be made for doing so.

${ }^{4}$ In its full philosophical sense, of course, realism refers to the belief that there are objects which exist independently of our perception of them. In this sense, all costs are intellectual constructs sustained by social convention. The exposition in the main text takes direct costs to be real relative to the practice of cost accounting, not to the whole of the human perceptual apparatus.

\footnotetext{
${ }^{5}$ These claims are also attacked from the position that there are 'different costs for different purposes', but that is a question of the different cost objects or decisions to which costs can be attached, not whether these costs are real or conventional.

${ }^{6}$ An example is the argument against the allocation of indirect costs on a direct labour cost base quoted from Wilson and Chua below (see also Johnson and Kaplan, 1987). In logic, the fact that direct labour accounts for only a small proportion of total costs in many modern production processes is irrelevant to its
} 
appropriateness as an allocation base. If the merit of an allocation base were determined by its magnitude as a proportion total costs, the value of bought-in materials and components would be the automatic choice in many factories. Really the argument rests on a gut feeling that the destination of large chunks of overhead cannot possibly depend on the distribution of a small element of total cost. Whilst not quite a claim of know the truth of overhead allocation, this is still a claim to know the territory in which it lies.

${ }^{7}$ The terminology is intended to evoke Bhaskar's (1986) realist social theory, in which the real is taken to consist of 'mechanisms' which manifest themselves, not directly, but through the empirical. Thus in ABC the simplicities of a real 'mechanism' (Products consume activities and activities cause costs) are assumed to account for the complexities of empirical cost structures.

${ }^{8}$ In practice, the labour of superintendance is often excluded, and distributed arbitrarily amongst other activities (e.g. Innes and Mitchell, 1990). The point made in the main text is that some of the labour counted as actually expended upon activities is really indirect.

${ }^{9}$ Where, as is to be hoped, there are synergies between activities, the isolation of the value added by any one of them is actually impossible, for the same reason that it is impossible to assign income to particular assets.

${ }^{10}$ It was a difference in the tacit assumptions as to the variability of indirect costs gave rise to a recent controversy over ABC. To Piper and Whalley (1990, 1991) ABC fails to model cost behaviour because overhead costs do not necessarily vary with activity volume. Cooper's reply (1990b) was that ABC is a resource consumption model, not an expenditure model. He then added the immediate corollary that 'management must take actions to bring spending in line with resource consumption.' In other words, ABC is an expenditure model, and it correctly models the variation of indirect costs with activity volume only because management 'must' be ruthless enough to act on the information.

11 Similar claims have appeared from KPMG Management Consulting (Morrow and Hazell, 1992) and from a senior consultant with Coopers and Lybrand (Hixon, 1995). A quotation from Hixon is given on page 18.

${ }^{12}$ Given the complex interdependencies of modern organizations, the question of whether activities are performed 'for' other functions is one for rhetoric and argument rather than appeal to the 'facts'. At the margin, this may mean that what qualifies as an activity may have much to do with the relative negotiating skills of service department managers and management accountants. 
${ }^{13}$ Ironically, there are signs that TCO may be in the process of reinvention as an extension of ABC, in which the costs of the activities associated with ownership are traced to individual suppliers (Clarke, 1994).

${ }^{14}$ I am indebted to Rolland Munro for this observation.

\section{References}

Acton, D.D. and Cotton, W.D.J. (1997) Activity-based costing in a university setting. Journal of Cost Management, (USA), Mar/Apr., Vol. 11, No. 2, pp. 32-38.

Adams, M. (1996) Activity-Based Costing (ABC) and the Life-Insurance Industry. Service Industries Journal, Vol. 16, No., pp. 511-526.

Aird, B. (1996) Activity-based cost management in health care - another fad? International Journal of Health Care Quality Assurance, (UK), Vol. 9, No. 4, pp. 16-19

Argenti, J. (1968) Corporate Planning: a Practical Guide. London. Allen \& Unwin.

Argyris, C. and Kaplan, R.S. (1994) Implementing New Knowledge: the Case of Activity-Based Costing. Accounting Horizons, Vol. 8, No. 3, Sept. pp. 83-105.

Armitage, H. and Russell, G. (1993) Activity-based management information: TQM's missing link. CMA Magazine, (Canada), Vol. 67, No. 2 Mar. p. 7.

Armstrong, P. (1984) Competition between the Organisational Professions and the Evolution of Management Control Strategies. Chapter 7 in Thompson, K (Ed.) Work, Employment and Unemployment Milton Keynes, Open University Press. pp., 97-120.

Armstrong, P. (1985) Changing Management Control Strategies - the role of competition between Accountancy and other organisational professions. Accounting, Organizations and Society. 10, 2 pp. 129-148

Armstrong, P. (1991) Contradictions and Social Dynamics in the Capitalist Agency Relationship. Accounting, Organizations and Society Vol. 16, No 1, pp. 1-25.

Armstrong, P. (1994) Corporate Control in Large British Companies: the intersection of management accounting and industrial relations in postwar Britain. Chapter 8 in Accounting as a Social and Institutional Practice. Eds. Hopwood, A. and Miller, P. Cambridge University Press. pp. 190-211.

Armstrong, P. (1995) Why do Accountants Write Plays About Direct Costing? Advances in Public Interest Accounting Vol. 6. pp. 1-18.

Armstrong, P. in press Designer Accountability: the Managerial Semiotics Project. Forthcoming in Critical Perspectives on Accounting.

Armstrong, P., Marginson, P., Edwards, P. and Purcell, J. (1996a) Budgetary Control And The Labour Force: Findings From A Survey Of Large British Companies. Management Accounting Research. Vol. 7 No 1. pp. 1-23.

Armstrong, P. and Tomes, A. (1996b) Art and Accountability: the Languages of Design and Managerial Control. Accounting, Auditing and Accountability Journal. Vol. 9, No. 5. pp. 114-125.

Armstrong, P., Marginson, P., Edwards, P. and Purcell, J. (1999) Accounting for Insecurity. Forthcoming in Critical Perspectives on Accounting. 
Atkinson, J. (1984) Manpower Strategies for Flexible Organizations Personnel Management. August. pp. 28-31

Babad, Y.M., Balachandran, B.V. (1993) Cost Driver Optimization in Activity-Based Costing. Accounting Review, Vol. 68, No., pp. 563-575.

Baily, P. and Farmer, D. (1990) Purchasing Principles and Management. London. Pitman. (6th edition).

Banker, R.D. and Johnston, H.H. (1993) An Empirical Study of Cost Drivers in the United-States Airline Industry. Accounting Review, Vol. 68, No. 3, pp. 576-601.

Bhaskar, R. (1986) Scientific Realism and Human Emancipation. London. Verso.

Bhimani, A. and Pigott, D. (1992) Implementing ABC: a Case Study of the Organisational Consequences. Management Accounting Research, Vol. 3, pp. 119-132.

Borjesson, S. (1994) What Kind Of Activity-Based Information Does Your Purpose Require - 2 Case Studies. International Journal of Operations \& Production Management, Vol.14, No.12, pp.79-99.

Bougen, P. (1989) The Emergence, Roles and Consequences of an Accounting-Industrial Relations Interaction. Accounting, Organisations and Society. Vol 14. No. 3. pp. 203-234.

Braverman, H (1974) Labor and Monopoly Capital. New York. Monthly Review Press.

Burt, D.N., Norquist, W.E. and Anklesaria, J. (1990) Zero Based Pricing. Chicago Ill. Probus Publishing.

Carr, L.P. and Ittner, C.D. (1992) Measuring the Cost of Ownership. Journal of Cost Management. Fall pp. 42-51.

Cavatino, J.L. (1992) A Total Cost/Value Model for Supply Chain Competitiveness. Journal of Business Logistics. Vol. 13, No. 2, pp. 285-301.

Child, J., Fores, M., Glover, I. and Lawrence, P. (1983) A Price to Pay? Professionalism and Work Organisation in Britain and West Germany. Sociology, Vol 17, No 1 pp. 63-78

Chua, W.F. and Preston, A. (1994) Worrying about Acounting in Health Care Accounting, Auditing and Accountability Journal. Vol 7 No 3 pp. 4-17.

Clarke P. and Bellis-Jones, R. (1996) Activity-based cost management in the management of change. The TQM Magazine, (UK), Vol. 8, No 2, pp. 43-48

Clarke, P.J. (1994) Activity-based cost management Accountancy Ireland, (Ireland), Oct. Vol. 26, No. 5, pp. 16-17.

Cochrane, A. (1993) From Financial Control to Strategic Management: the Changing Face of Accountability in British Local Government. Accounting, Auditing and Accountability Journal. Vol 6, No 3. pp 30-51

Cooper, R. and Kaplan, R.S. (1991) The Design of Cost Management Systems: Text, Cases and Readings. Englewood Cliffs, New Jersey. Prentice-Hall.

Cooper, R. (1990a) Implementing an Activity-Based Costing System. Journal of Cost Management (Spring) pp. 33-42. Reprinted in Cooper and Kaplan (1991) pp. 386-395.

Cooper, R. (1990b) Explicating the Logic of ABC. Management Accounting (CIMA) Vol 68 No. 10. (Nov.) pp. 58-60.

Cooper, R., Kaplan, R.S., Maisel, L.S., Morrisey, E. and Oehm, R.M. (1992) Implementing activity-Based Cost Management: Moving from Analysis to Action: 
experiences at eight companies. Institute of Management Accountants (USA)/Peat Marwick.

Curtown, Earl of (1960) Address to the $11^{\text {th }}$ Summer School of the Institute of Chartered Accountants, England and Wales. The Cost Accountant. Nov. pp. 394-401

Danilenko, G. (1994) Activity-Based Costing for Services - The Corporate Information Center. Special Libraries, Vol.85, No.1, pp.24-29.

Datar, S. and Gupta, M. (1994) Aggregation, Specification and Measurement Errors in Product Costing. Accounting Review, Vol.69, No.4, pp.567-591.

Dugdale, D. (1990) Costing Systems in Transition: a Review of Recent Developments. Management Accounting (CIMA) Vol 68, No. 1. (Jan) pp. 38-41.

Ellram, L.M. (1993) Total Cost of Ownership: Element and Implementation. International Journal of Purchasing and Materials Management. Vol. 29, No. 4, pp. 311.

Ellram, L.M. (1995) Activity-Based Costing and Total Cost of Ownership: a Critical Linkage. Journal of Cost Management, Vol. 8, No. 4. pp. 22-30.

Ellram, L.M. and Maltz, A.B. (1995) The Use of Total Cost of Ownership to Model the Outsourcing Decision. The International Journal of Logistics Management. Vol. 6, No. 2, p. 55.

Ellram, L.M. and Siferd, S.P. (1993) Purchasing: The Cornerstone of the Total Cost of Ownership Concept. Journal of Business Logistics. Vol. 14 No 1.

Evans, H. and Ashworth, G. (1995) Activity-based management: moving beyond adolescence. Management Accounting (CIMA), Vol. 73, No. 11, Dec. pp. 26-30.

Ezzamel, M. and Willmott, H. (1993) Corporate Governance and Financial Accountability: Recent reforms in the UK Public Sector Accounting, Auditing and Accountability Journal. Vol 6, No 3. pp 109-132

Freedman, M. (1976) The Search for Shelters Labor Markets, Segmentation and Shelters. New York. Allanhead, Osman/Universal Books. Ch. 7. Reprinted as Ch. 4 pp. 55-66. in in Thompson, K (ed.) Work, Employment and Unemployment. Milton Keynes, Open University Press.

Gadde, L-E and Håkansson, H. (1993) Professional Purchasing. London. Routledge.

Gellner, E. (1970) Concepts and Society. Ch 2 pp. 18-49 in Wilson, B. R. (ed) Rationality. Oxford. Blackwell.

Gordon, D.M., Edwards, R.C. and Reich, M. (1982) Segmented Work, Divided Workers: the Historical Transformation of Labor in the United States. Cambridge. Cambridge University Press.

Gray, A. and Jenkins, W. (1993) Codes of Accountability in the New Public Sector. Accounting, Auditing and Accountability Journal. Vol 6, No 3. pp 52-67

Groot, T.L.C.M. (1997) When Activity-Based Management Leads to the Abolition of Activity-Based Costing. Working paper. Vrije Universiteit. Quoted in Lindahl, F. W. (1997) Activity-based costing implementation and adaptation. Human Resource Planning, (USA), Vol. 20, No 2, pp. 62-66.

Hayes. R.H. and Abernathy, W.J. (1980) Managing Our Way to Economic Decline. Harvard Business Review. July-Aug. pp 67-77. 
Hiromoto, T. (1988) Another Hidden Edge: Japanese Management Accounting. Harvard Business Review. Reprinted in Cooper and Kaplan (1991) pp. 461-465.

Hixon, M. (1995) Activity-based management: its purpose and benefits. Management Accounting (CIMA), Vol. 73, No. 6, pp. 30-31.

Hobdy ,T., Thomson, J. and Sharman, P. (1994) Activity-based management at AT\&T. Management Accounting, (USA), Apr. Vol. 75, No. 10, pp. 35-39

Hollis, M. (1970) The Limits of Irrationality. Ch 10 in Wilson, B. R. (ed) Rationality. Oxford. Blackwell.

Horngren, C.T. (1990) First Discussant. Journal of Management Accounting Research. Fall. pp. 21-24.

Humphrey, C., Miller, P. and Scapens, R. (1993) Accountability and Accountable Management in the UK Public Sector Accounting, Auditing and Accountability Journal. Vol 6, No 3. pp 7-29

Innes, J. and Mitchell, F. (1990) Activity Based Costing: a Review with Case Studies. London. The Chartered Institute of Management Accountants.

Innes, J. and Mitchell, F. (1990) Activity-Based Costing Research. Management Accounting (CIMA) Vol 68 No. 5. (May) pp. 28-29.

Innes, J., Mitchell, F. and Cobb, I. (1992) Activity-Based Costing: Problems in Practice. London. CIMA.

Jeans, M and Morrow, M (1989) The Practicalities of Using Activity-Based Costing. Management Accounting. Nov. p. 42-44

Johnson, H.T. (1988) Activity-Based Information: a Blueprint for World-Class Management Accounting. Management Accounting (US) June pp. 23-30. Reprinted in Cooper and Kaplan (1991) pp. 257-266.

Johnson, H.T. and Kaplan, R.S. (1987) Relevance Lost: the Rise and Fall of Management Acounting. Boston Massachusetts. Harvard Business School Press.

Kaplan, R.S. (1985) Accounting Lag: the Obsolescence of Cost Accounting Systems in Clark, K.B., Hayes, R.H. and Lorenz, C.L. (Eds.) The Uneasy Alliance: Managing th Productivity-Technology Dilemma. Reprinted in Cooper and Kaplan (1991). pp. 63-79.

Kaplan, R.S. (1987b) John Deere Component Works (A). Reprinted in Prentice-Hall. pp. 291-303.

Kaplan, R.S. (1987a) Regaining Relevance. Session 7 in Capettini, R. and Lang, D.K. (eds.) Cost Accounting, Robotics and the New Manufacturing Environment. Edited papers from the 1st Annual Management Accounting symposium. Sarasota, Florida . American Accounting Association. pp. 7.1-7.29

Kaplan, R.S. (1988) One Cost System isn’t Enough. Harvard Business Review. Vol 68, No. 1, pp. 61-66.

Kennedy, A. (1995) ABC Basics. Management Accounting (CIMA) June. pp. 23-24.

Lammert, T.B. and Ehrsam, R. (1987) The Human Element: the Real Challenge in Modernising Cost Systems. Reprinted in Cooper and Kaplan (1991) pp. 445-449.

Laughlin, R., Broadbent, J. and Willing-Atherton, H. (1994) Recent Financial and Administrative Changes in GP Practices in the UK: Initial Experiences and Effects. Accounting, Auditing and Accountability Journal. Vol 7 No 3. pp. 96-124 
Lawrence, S., Manzurul, A. and Lowe, A. (1994) The Great Experiment: Financial Management Reform in the NZ Health Sector Accounting, Auditing and Accountability Journal. Vol 7 No 3. pp. 68-95

Lawson, R.A. (1994) Activity-based costing systems for hospital management. CMA Magazine, (Canada), June, Vol. 68, No. 5, pp. 31-35

Lere, J.C. and Saraph, J.V. (1995) Activity-based costing for purchasing managers' cost and pricing determinations. International Journal of Purchasing and Materials Management, (USA), Autumn, Vol. 31, No. 4, pp. 25-31

Letza, S.R. and Gadd, K. (1994) Activity-based costing as the method of choice for total quality organizations? The TQM Magazine, (UK), Vol 6 No 5, pp. 57-63

Lindahl, F. W. (1997) Activity-based costing implementation and adaptation. Human Resource Planning, (USA), Vol. 20, No 2, pp. 62-66.

Lyne, S. and Friedman, A. (1996) Activity-based techniques and the 'new management accountant' Management Accounting, (CIMA), Jul/Aug. Vol. 74, No. 7, pp. 34-35.

Marshall, B. (1995) Activity-based costing at Wavin. Management Accounting, (UK), May, Vol. 73, No. 5, pp. 28 -30.

Merton, R.K. (1940) Bureaucratic Structure and Personality. Social Forces. Vol. 18, pp. 560-568.

Miller, P. and O'Leary, T. (1987) Accounting and the Construction of the Governable Person. Accounting, Organisations and Society. Vol 12. No 3. pp. 235-265.

Morrow, M. and Connolly, T. (1991) The Emergence of Activity-Based Budgeting. Management Accounting (UK) February. pp. 38-41.

Morrow, M. and Hazell, M. (1992) Activity Mapping for Business Process Redesign. Management Accounting, (UK), Feb Vol. 70, No. 2, pp. 36-38.

Mouzelis, N. (1995) Sociological Theory: What Went Wrong? Diagnosis and Remedies. London. Routledge.

Noreen, E. (1991) Conditions Under Which Activity-Based Costing Systems Provide Relevant Costs. Journal of Management Accounting Research. Vol. 3, Fall. pp. 159-168.

Ogden, S. (1995) Transforming Frameworks of Accountability: the Case of Water Privatisation. Accounting, Organisations and Society, Vol 20 Nos 2/3 pp. 193-218

Parkinson, C.N. (1965) Parkinson's Law or the Pursuit of Progress. Harmondsworth. Penguin.

Pattison, D.D. and Gavan, Arendt C. (1994) Activity-based costing: it doesn't work all the time Management Accounting, (USA), Apr. Vol. 75, No. 10, pp. 55-62

Piore, M.J. and Sabel, C.F. (1984) The Second Industrial Divide: Possibilities for Prosperity. New York. Basic Books.

Piper, J.A. and Walley, P. (1990) Testing ABC Logic. Management Accounting (CIMA) Vol 68 No. 8. (Sept.) pp. 37, 42.

Piper, J.A. and Walley, P. (1991) ABC Relevance Not Found. Management Accounting (CIMA) Vol 69 No. 3. (March.) pp. 42, 44, 54.

Roehm, H.A., Critchfield, M.A. and Castellano, J.F. (1992) Yes, ABC Works With Purchasing, Too. Journal of Accountancy, Vol.174, No.5, pp.58-62. 
Ruhl, J.M. and Bailey, T.A. (1994) Activity-based costing for the total business. The CPA Journal, (USA), Feb. Vol. 64, No. 2, pp. 34-38

Saunders, M. (1997) Strategic Purchasing and Supply Chain Management. 2nd ed. London. Pitman

Sephton, M. and Ward, T. (1990) ABC in Retail Financial Services Management Accounting (CIMA) April. pp 32-33

Shields, M.D. (1995) An Experimental Analysis of Firm's Experiences with ActivityBased Costing. Journal of Management Accounting Research. Vol. 7, pp. 148-166.

Shields, M.D. and Young, S.M. (1989) A Behavioural Model for Implementing Cost Management Systems. Journal of Cost Management (Winter) pp. 17-27. Reprinted in Cooper and Kaplan (1991) pp. 450-460.

Skinner, W. (1985) Manufacturing - the Formidable Competitive Weapon. New York. John Wiley.

Smytka, D.L. and Clemens, M.W. (1993) Total Cost Supplier Selection Model. International Journal of Purchasing and Materials Management. Vol. 29, No. 1 (Winter), p. 42.

Staubus, G.J. (1990) Activity Costing Twenty Years On. Managment Accounting Research. Vol. 1, pp. 249-264.

Steimer, T.E. (1990) Activity-based accounting for total quality. Management Accounting, (USA), Oct. Vol. 72, No. 4, pp. 39-42

Thomas, M. F. and Mackey, J.T. (1994) Activity-based cost variances for just-in-times. Management Accounting, (USA), Apr. Vol. 75, No. 10, pp. 49-54

Thomas, W.I. (1957) The Unadjusted Girl: with Cases and Standpoint for Behaviour Analysis. Little Brown.

Torrington, D and Mackay, L. (1986) Will Consultants Take over the Personnel Function? Personnel Management. February. pp. 34-7.

Tyson S. (1985) Is this the Very Model of a Modern Personnel Manager? Personnel Management, Vol. 7, No. 5, pp. 10-16

West, D.A., Hicks, L.L., Balas, E.A. and West, T.D. (1996) Profitable Capitation Requires Accurate Costing. Nursing Economics, Vol.14, No.3, p.162.

Wilson, R.M.S. and Chua, W.F. (1993) Management Accounting: Method and Meaning London. Chapman and Hall

Winch, P. (1970) Understanding a Primitive Society. Ch 5 pp. 78-111 in Wilson, B. R. (ed) Rationality. Oxford. Blackwell. 